\title{
ZNACZENIE POLICJI W SYSTEMIE BEZPIECZEŃSTWA WEWNĘTRZNEGO PAŃSTWA
}

\begin{abstract}
Streszczenie: Polska Policja jest formacją umundurowaną i uzbrojoną, podległą ministrowi właściwemu do spraw wewnętrznych, powołaną przez ustawodawczą władzę państwową do zapewnienia bezpieczeństwa ludzi znajdujących się na terytorium państwa polskiego oraz utrzymywania zarówno bezpieczeństwa publicznego, jak i porządku publicznego. Do jej głównych zadań należy przeciwdziałanie przestępczości, ujawnianie przestępstw i ściganie ich sprawców. Funkcjonowanie Policji, mające naturę administracji publicznej, wpisuje się w funkcjonowanie całego systemu bezpieczeństwa państwa, w tym również w tę jego część, która nosi miano systemu bezpieczeństwa wewnętrznego państwa. Funkcjonowanie systemu bezpieczeństwa wewnętrznego przyjmuje formę procesu bezpieczeństwa zwanego bezpieczeństwem wewnętrznym. Tak ujmowane bezpieczeństwo wewnętrzne to zamierzona aktywność elementów systemu bezpieczeństwa wewnętrznego, realizowana w ramach strategicznej polityki bezpieczeństwa narodowego, przejawiająca się głównie ochroną bezpieczeństwa publicznego i bezpieczeństwa powszechnego. Analizując funkcjonowanie Policji nasuwa się pytanie: $\mathrm{z}$ czego wynika znaczenie tej formacji dla funkcjonowania tego systemu? W odniesieniu do problemu badawczego postawiono hipotezę o treści: Znaczenie Policji w systemie bezpieczeństwa wewnętrznego wynika ze zdolności tej formacji do prowadzenia działań wiodących w sferze utrzymywania bezpieczeństwa publicznego oraz działań wspomagających w sferze utrzymywania bezpieczeństwa powszechnego. W badaniu zastosowane metodę badawczą: badanie dokumentów, techniką jakościową. W toku przeprowadzonego badania hipoteza została uznana za prawdziwą, a problem badawczy został rozwiązany.
\end{abstract}

Stowa kluczowe: policja, system bezpieczeństwa wewnętrznego, współdziałanie.

\section{Роберт Гвардинський, Університет Нижньої Сілезї̈ у Вроџлаві}

\section{РОЛЬ ПОЛІЩЇ̈ В ДЕРЖАВНІЙ СИСТЕМІ ВНУТРІШНЬОЇ БЕЗПЕКИ}

\begin{abstract}
Анотація: Польська поліція — це уніформоване та збройне формування, підпорядковане міністру внутрішніх справ, яке призначається державним законодавчим органом для забезпечення безпеки людей на території польської держави та підтримки громадської безпеки та громадського порядку. Її основні завдання - запобігання злочинам, розкриття злочинів та притягнення до відповідальності винних. Функціонування поліції, що має характер державного управління, є частиною функціонування всієї системи державної безпеки, у тому числі тієї іiі частини, яка називається системою внутрішньої безпеки держави. Функціонування системи внутрішньої безпеки відбувається у формі процесу безпеки, який називається внутрішньою безпекою. Під внутрішньою безпекою розуміють цілеспрямовану діяльність елементів системи внутрішньої безпеки, що реалізується як частина стратегічної політики національної безпеки, що виявляється переважно у захисті громадської безпеки та загальної безпеки. Аналізуючи функціонування поліції, виникає питання: чим обумовлено значення цієї державної структури для функціонування цієї системи? Щодо досліджуваної проблеми висунута гіпотеза: значення поліції в системі внутрішньої безпеки виникає зі здатності цього формування державної структури здійснювати керівну діяльність у сфері забезпечення громадської безпеки та допоміжну діяльність у сфері підтримання громадської безпеки. Метод дослідження, використаний при дослідженні: експертиза документів, якісна методика. У ході дослідження гіпотеза була визнана вірною і проблема дослідження була вирішена.
\end{abstract}

Ключові слова: поліція, система внутрішньої безпеки, співпраця.

Robert Gwardyński, University of Lower Silesia in Wroctaw

\section{IMPORTANCE OF THE POLICE IN THE STATE INTERNAL SECURITY SYSTEM}

Abstract: The Polish Police is a uniformed and armed formation, subordinate to the minister competent for internal affairs, appointed by the legislative state authority to ensure the safety of people on the territory of the Polish state and to maintain both public security and public order. Its main tasks include preventing crime, exposing crimes and 
prosecuting their perpetrators. The functioning of the Police is part of the functioning of the state security system, including the part of it that bears the name of the internal security system of the state. The functioning of the internal security system takes the form of a security process called internal security. Internal security understood in this way is the intentional activity of elements of the internal security system, implemented as part of the strategic national security policy, manifested mainly by the protection of public security and public security. Analysing the functioning of the Police, the question arises: what is the reason for the importance of this formation for the functioning of this system? Concerning the research problem, a hypothesis was formulated: The importance of the Police in the internal security system results from the ability of this formation to conduct leading activities in the field of maintaining public safety and supporting activities in the field of maintaining public security. The research method used in the study: an examination of documents, qualitative technique. In the course of the research, the hypothesis was found to be true and the research problem was solved.

Keywords: police, internal security system, cooperation.

\section{Wprowadzenie}

Współczesne państwo demokratyczne jest wytworem kulturowym społeczeństwa. Najlepszym gwarantem jego przetrwania, umożliwiającym zaspokajanie potrzeb indywidualnych i zbiorowych swoich obywateli [1]. Jego celem jest szczęście mieszkańców [2] oraz zapewnienie bezpieczeństwa, które owemu szczęściu sprzyja [3]. Jako, że na bezpieczeństwo można spoglądać przez pryzmat zmiany (procesu [4]) albo stanu (rzeczy [5] lub myśli o rzeczy [6]), to i w takim ujęciach można dostrzegać bezpieczeństwo państwa [7].

Proces bezpieczeństwa to pewna forma funkcjonowania podmiotu działania (jednostki ludzkiej, zespołu, instytucji [8]) dążącego - według Stanisława Kozieja - „do zapewnienia możliwości przetrwania, rozwoju i swobody realizacji własnych interesów w konkretnych warunkach, poprzez wykorzystywanie okoliczności sprzyjających (szans), podejmowanie wyzwań, redukowanie ryzyka oraz przeciwdziałanie (zapobieganie i przeciwstawienie się) wszelkim zagrożeniom dla podmiotu i jego interesów" [9]. Proces bezpieczeństwa państwa narodowego może być utożsamiany z bezpieczeństwem narodowym, obejmującym jak pisze Waldemar Kitler - ,różnorodne środki, gwarantujące trwały, wolny od zakłóceń byt i rozwój narodowy (państwa), w tym ochronę i obronę państwa jako instytucji politycznej oraz ochronę jednostek i całego społeczeństwa, ich dóbr i środowiska naturalnego przed zagrożeniami, które w znaczący sposób ograniczają jego funkcjonowanie lub godzą w dobra podlegające szczególnej ochronie" [10]. Częścią procesu bezpieczeństwa państwa jest m.in. obronność, rozumiana jako suma przedsięwzięć mających na celu jak pisze Bernard Wiśniewski - „zapobieganie i przeciwstawienie się zagrożeniom bezpieczeństwa państwa, zarówno militarnym, jak i pozamilitarnym, mogącym doprowadzić do kryzysu polityczno-militarnego" [11].

Bezpieczeństwo państwa może być również widziane jako stan jego niezagrożenia. Ów stan posiada wymiar obiektywny (stan rzeczy) oraz subiektywny (stan myśli o rzeczy, objawiający się $\mathrm{w}$ poczuciu bezpieczeństwa) składający się na sytuację zewnętrzną i wewnętrzną podmiotu bezpieczeństwa. Jeśli przyjąć, że obiektywnie istniejące zmiany i stany rzeczy oraz stosunek do nich człowieka tworzy jego sytuację [12], to bezpieczeństwo jest szczególnym jej rodzajem, charakteryzującym się brakiem ryzyka utraty czegoś, co ten jednostka ludzka szczególnie ceni [13]. Bezpieczeństwo podmiotu służy wyższym wartościom i dobru (np. szczęściu, rozwojowi, wolności jednostki i grupy). Jest również wartością i dobrem samym w sobie, przynależnym bez wyjątku każdemu członkowi społeczeństwa [14]. Bezpieczeństwo państwa jest dobrem wspólnym wszystkich członków wspólnoty państwowej jako, że ta nazwa odnosi się do pewnej kategorii opisującej pozytywną wartość zbiorową „...osiąganą przez wspólnoty ludzkie w związku z rozwijaniem naturalnych możliwości ich członków, zaspokojeniem ich indywidualnych interesów lub respektowaniem posiadanych przez nich uprawnień, przy jednoczesnej dbałości o zbliżanie całej wspólnoty ku właściwym jej celom" [15].

Państwo będąc - jak piszą: Andrzej Antoszewski i Teresa Łoś-Nowak - wspólnotą polityczną obejmującą zarówno konkretną zbiorowość społeczną zamieszkującą określone terytorium i podporządkowaną jednemu ośrodkowi władzy, jak i zespół norm politycznych [16] pełni wiele funkcji. Stanisław Ehrlich wyróżnia ich cztery (zewnętrzną, wewnętrzną, społeczno-gospodarczą i kulturalną [17]); Waldemar. Kitler wyróżnia ich pięć (wewnętrzną, zewnętrzną, gospodarczo-organizatorską, socjalną, kulturalno-wychowawczą [18]); Bernard Wiśniewski wyróżnia ich siedem (zewnętrzną, wewnętrzną socjalną, adaptacyjną, regulacyjną, oraz gospodarsko organizatorską i innowacyjną [19]). Dla bezpieczeństwa państwa szczególne znaczenie mają funkcje: zewnętrzna i wewnętrzna.

Funkcja zewnętrzna dotyczy zapewnienia przez państwo warunków zewnętrznych, sprzyjających jego harmonijnemu rozwojowi oraz sprawnemu działaniu (zapewnienie bezpieczeństwa $\mathrm{w}$ stosunkach $\mathrm{z}$ innymi państwami). Funkcja wewnętrzna obejmuje - według Andrzeja Antoszewskiego i Teresy Łoś-Nowak oprócz formułowania celów i sposobów zaspokajania potrzeb ludności w ramach administracji publicznej oraz gromadzenia zasobów niezbędnych celom politycznym, również:

- wprowadzanie norm prawnych regulujących zachowania indywidualne i zbiorowe obywateli; 
-interweniowanie w przypadku naruszenia obowiązujących norm prawnych [20].

Odnosząc się do powyższego i mając na względzie bezpieczeństwo państwa, można przyjąć za Bernardem Wiśniewskim, że funkcja wewnętrzna w głównej mierze sprowadza się do ,zapewnienia porządku i bezpieczeństwa wewnątrz kraju, co osiąga się przez działanie organów administracyjnych państwa" [21]. Państwo jest organizacją w sensie rzeczowym [22], a jego funkcja wewnętrzna umożliwia utrzymywanie go w stanie niezbędnej dla jego funkcjonowania równowagi wewnętrznej (zdolność taka w organizmie nosi miano homeostazy [23]). Równowaga wewnętrzna państwa jest jego racją stanu. Michel Foucault pisze o niej: „W sensie obiektywnym racją stanu nazywa się wszystko, co jest niezbędne i wystarczające do tego, by państwo (...) mogło zachować swoją spójność" [24]. Racją stanu jest zatem równowaga utrzymująca się pomiędzy dominium państwa, jego prawem oraz społeczeństwem. Racji stanu sprzyja utrzymywanie bezpieczeństwa wewnętrznego państwa. Bernard Wiśniewski definiuje je jako stan albo proces ,uzyskany w efekcie spełniania przez państwo funkcji wewnętrznej realizowanej w ramach strategicznej polityki bezpieczeństwa narodowego, przejawiający się ochroną:

-w ujęciu wąskim - bezpieczeństwa publicznego, bezpieczeństwa powszechnego oraz bezpieczeństwa ustrojowego;

-w ujęciu szerokim - porządku konstytucyjnego, życia i zdrowia obywateli, majątku narodowego przed bezprawnymi działaniami, a także skutkami klęsk naturalnych i katastrof technicznych" [25].

W Rzeczpospolitej Polskiej zapewnienie bezpieczeństwa wewnętrznego należy do zadań Rady Ministrów kierowanej przez Prezesa Rady Ministrów (premiera) [26].W jej skład wchodzi minister właściwy do spraw wewnętrznych kierujący działem administracji rządowej „Dział sprawy wewnętrzne” obejmujący między innymi: ochronę bezpieczeństwa i porządku publicznego; ochronę granicy państwowej, kontrolę ruchu granicznego i cudzoziemców; koordynację działań związanych z polityką migracyjną państwa; zarządzanie kryzysowe; obronę cywilną; ochronę przeciwpożarową [27]. Minister właściwy do spraw wewnętrznych sprawuje nadzór nad działalnością Policji - instytucji powołanej do ochrony bezpieczeństwa ludzi oraz utrzymywania bezpieczeństwa i porządku publicznego [28] i będącej elementem systemu bezpieczeństwa wewnętrznego państwa.

Celem niniejszego opracowania jest określenie znaczenia Policji w systemie bezpieczeństwa wewnętrznego państwa na przykładzie formacji policyjnej funkcjonującej w Polsce.

\section{Założenia metodologiczne pracy}

Przedmiotem badań jest funkcjonowanie elementu systemu bezpieczeństwa wewnętrznego państwa $\mathrm{w}$ sferze zapewnienia bezpieczeństwa ludziom oraz utrzymywania bezpieczeństwa i porządku publicznego.

Problem badawczy sformułowano jako pytanie: Z czego wynika znaczenie Policji dla funkcjonowania systemu bezpieczeństwa wewnętrznego państwa? W odniesieniu do problemu badawczego postawiono hipotezę o treści: Znaczenie Policji w systemie bezpieczeństwa wewnętrznego wynika ze zdolności tej formacji do prowadzenia działań wiodących w sferze utrzymywania bezpieczeństwa publicznego oraz działań wspomagających w sferze utrzymywania bezpieczeństwa powszechnego.

W badaniu zastosowane metodę badawczą: badanie dokumentów, techniką jakościową. W badaniu wykorzystano dokumenty w postaci literatury naukowej, sprawozdań statystycznych, aktów prawnych, informacji publicznej udostępnionej przez urzędy państwowe.

\section{Zadania Policji w sferze bezpieczeństwa publicznego}

Policja jest elementem systemu bezpieczeństwa wewnętrznego [29] - rozumianego za Bernardem Wiśniewskim jako ogół podmiotów wykonujących określone funkcje (obowiązki) związane z zapewnieniem funkcjonowania struktur państwa oraz ochroną ludności i majątku narodowego przed skutkami oddziaływań kryzysowych [30] - oraz podsystemu bezpieczeństwa publicznego [31].

Pojęcie bezpieczeństwa publicznego nie jest jednoznaczne. Waldemar Kitler efiniuje je jako działania „majace na celu ochronę porządku prawnego w państwie przed działaniami zabronionymi, a także takimi, które godzą w życie i zdrowie ludzkie oraz porządek publiczny, obyczaje i normy społeczne, jak również instytucje (w tym całą infrastrukturą społeczną) i urządzenia publiczne (m.in. drogi, szlaki kolejowe, sieci energetyczne, urządzenia przemysłowe, wody, gazu)" [32]. Zbigniew Ściborek dostrzega w nim ,ogół warunków i instytucji chroniących życie, zdrowie, mienie obywateli, majątek ogólnonarodowy, ustrój i suwerenność państwa przed zjawiskami groźnymi dla ładu prawnego, a także przed zjawiskami mogącymi zakłócić normalne funkcjonowanie obywateli, godzącymi W ogólnoprzyjęte normy postępowania [33]. Tomasz Serafin i Sergiusz Parszowski definiuje je jako, ,stan gwarantujący niezakłócone i zgodne z wolą obywateli funkcjonowanie instytucji państwowych, samorządowych i społecznych oraz urządzeń publicznych, a także bezpieczeństwo życia, zdrowia i mienia ludności w wyniku przestrzegania akceptowanego przez obywateli porządku prawnego" [34]. Podsumowując można powiedzieć za Aleksandrem Babińskim, że „bezpieczeństwo publiczne jest pozytywnym stanem w 
państwie, osiągniętym $\mathrm{w}$ wyniku realizacji polityki bezpieczeństwa, w którego zakres wchodzi państwo ze swoim ustrojem i innymi urządzeniami, a także osoby pozostające pod jurysdykcją ich życie, zdrowie i mienie" [35].

Do głównych zadań polskiej Policji w sferze utrzymywania bezpieczeństwa i porządku publicznego należy m.in.:

- ochrona życia i zdrowia ludzi oraz mienia przed bezprawnymi zamachami naruszającymi te dobra;

- ochrona bezpieczeństwa i porządku publicznego;

- inicjowanie i organizowanie działań mających na celu zapobieganie popełnianiu przestępstw $i$ wykroczeń oraz zjawiskom kryminogennym i współdziałanie $\mathrm{w}$ tym zakresie $\mathrm{z}$ organami państwowymi, samorządowymi i organizacjami społecznymi;

- prowadzenie działań kontrterrorystycznych;

- wykrywanie przestępstw i wykroczeń oraz ściganie ich sprawców;

- ochrona obiektów stanowiących siedziby członków Rady Ministrów;

-współdziałanie z policjami innych państw oraz ich organizacjami międzynarodowymi, a także $z$ organami i instytucjami Unii Europejskiej na podstawie umów i porozumień międzynarodowych oraz odrębnych przepisów [36].

Realizując powyższe zadania Policja wykonuje czynności administracyjnoporządkowe, dochodzeniowo-śledcze, operacyjno-rozpoznawcze m.in. w celu: rozpoznawania, zapobiegania i wykrywania przestępstw i wykroczeń oraz poszukiwania osób ukrywających się przed organami ścigania lub wymiaru sprawiedliwości.

Mając na względzie, że podstawowym zagrożeniem bezpieczeństwa publicznego jest przestępczość, a jego źródłem między innymi aspołeczne zachowania Policja kooperuje $\mathrm{z}$ podmiotami będącymi elementami systemu bezpieczeństwa publicznego takimi jak:

- organy administracji rządowej (np. Rada Ministrów [37], wojewodowie [38]);

- instytucje rządowe (np. prokuratura [39], Straż Graniczna [40], Żandarmeria Wojskowa [41], Służba Ochrony Państwa [42], Agencja Bezpieczeństwa Wewnętrznego [43]);

- organy samorządowe (np. zarząd województwa [44], starosta [45], wójt, burmistrz, prezydent miasta [46]);

-instytucje samorządowe (np. straże gminne, miejskie [47]);
- organizacje społeczne (np. straże osiedlowe, straże ogródkowe);

- prywatni przedsiębiorcy (np. firmy ochrony osób i mienia).

Współpraca Policji z pozostałymi podmiotami systemu bezpieczeństwa publicznego jest skonsolidowana od 2007 roku poprzez rządowy program ograniczania przestępczości i aspołecznych zachowań „Razem bezpieczniej”.

Założeniem programu od samego początku jego istnienia było wspieranie działań podejmowanych przez organy administracji rządowej i samorządu terytorialnego na rzecz bezpieczeństwa i porządku publicznego. Celem programu „Razem bezpieczniej” było i wspieranie inicjatyw lokalnych na rzecz poprawy bezpieczeństwa i porządku publicznego [48].

Policja jest główną instytucją państwa polskiego przeznaczoną do utrzymywania bezpieczeństwa publicznego poprzez ograniczanie przestępczości. W Strategii Bezpieczeństwa Narodowego Rzeczypospolitej Polskiej z 2014 roku, odnosząc się do charakterystyki działań ochronnych podsystemu operacyjnego napisano: „Podstawą utrzymania bezpieczeństwa i porządku publicznego na właściwym poziomie jest skuteczne zapobieganie ich naruszeniom, a także wykrywanie przestępstw i wykroczeń godzących w życie, zdrowie i mienie obywateli, jak również interesy państwa. Zadania realizowane w tym zakresie dotyczą różnego rodzaju czynów zabronionych, w tym zarówno przestępczości pospolitej, jak i zorganizowanej o charakterze ekonomicznym, narkotykowym i kryminalnym. Przedmiotowe działania pozostaną ukierunkowane na zwiększenie efektywności w zakresie przeciwdziałania i wykrywania przestępstw i wykroczeń, nieuchronności karania ich sprawców, odzyskiwania utraconego mienia oraz minimalizowania strat budżetu państwa. Istotną rolę odgrywać będzie również koordynacja działań i współpraca z innymi podmiotami systemu bezpieczeństwa narodowego, $\mathrm{w}$ tym $\mathrm{z}$ właściwymi organami administracji publicznej oraz wewnętrznymi służbami ochrony, a także partnerami zagranicznymi i międzynarodowymi. Najważniejszą służbą realizującą zadania $\mathrm{z}$ tego zakresu jest Policja, właściwa w zakresie ochrony życia i zdrowia oraz mienia przed bezprawnymi zamachami naruszającymi te dobra" [49].

\section{Zadania Policji w sferze bezpieczeństwa powszechnego}

Policja odnotowuje swój udział w działaniach podejmowanych $\mathrm{w}$ ramach systemu bezpieczeństwa powszechnego. Bezpieczeństwo powszechne jest obok bezpieczeństwa publicznego składnikiem bezpieczeństwa wewnętrznego. Podobnie jak bezpieczeństwo publiczne bezpieczeństwo powszechne jest różnie definiowane. Waldemar Kitler przez „bezpieczeństwo powszechne" rozumie pewien rodzaj bezpieczeństwa 
narodowego, będący ,procesem obejmującym szereg różnorodnych działań (m.in. w dziedzinach: zdrowotnej, ekologicznej, edukacyjnej, społecznej, gospodarczej, prawnej, psychologicznej, weterynaryjnej i sanitarnej), którego zasadniczym celem jest zapewnienie bezpieczeństwa ludności cywilnej, a zarazem stanem uzyskanym w wyniku zorganizowanej ochrony życia i zdrowia ludzi, dóbr materialnych i kulturalnych oraz środowiska naturalnego - w zakresie niezbędnym do przetrwania ludzi” [50]. Z kolei Zbigniew Ścibiorek dostrzega $\mathrm{w}$ bezpieczeństwie powszechnym ,stan otoczenia cywilizacyjnego i środowiska naturalnego, $\mathrm{w}$ którym obywatele i ich wspólnoty nie odczuwają zagrożenia swego istnienia ani podstawowych interesów życiowych, ze względu na zapewnienie przez państwo formalnych, instytucjonalnych i praktycznych gwarancji ochrony prowadzących do społecznie akceptowalnego ryzyka" [51].

Głównym zagrożeniem bezpieczeństwa powszechnego są klęski żywiołowe, do których zalicza się:

- awarie techniczne - będacee to gwałtownym, nieprzewidzianym uszkodzeniem lub zniszczeniem obiektu budowlanego, urządzenia technicznego lub systemu urządzeń technicznych powodujące przerwę w ich używaniu lub utratę ich właściwości;

- katastrofy naturalne - będące zdarzeniem związanym z działaniem sił natury, w szczególności wyładowaniami atmosferycznymi, wstrząsami sejsmicznymi, silnymi wiatrami, intensywnymi opadami atmosferycznymi, długotrwałym występowaniem ekstremalnych temperatur, osuwiskami ziemi, pożarami, suszami, powodziami, zjawiskami lodowymi na rzekach i morzu oraz jeziorach i zbiornikach wodnych, masowymi występowaniem szkodników, chorób roślin lub zwierząt albo chorób zakaźnych ludzi albo też działaniem innego żywiołu [52].

Wiodącą instytucją w zakresie utrzymywania bezpieczeństwa powszechnego jest Państwowa Straż Pożarna. Odnosząc się do niej w Białej Księdze Bezpieczeństwa Narodowego Rzeczypospolitej Polskiej napisano, że: ,Wśród służb ratownictwa i ochrony ludności pierwszoplanową rolę pełni Państwowa Straż Pożarna (PSP), będąca zawodową formacją powołaną do walki z pożarami, klęskami żywiołowymi i innymi miejscowymi zagrożeniami. W podsystemie ratownictwa i ochrony ludności PSP wspierana jest przez inne służby, straże i instytucje państwowe oraz przez sieć organizacji pozarządowych" [53]. Państwowa Straż Pożarna jest formacją zawodową, umundurowaną i wyposażoną w specjalistyczny sprzęt, której przeznaczeniem jest do walki z pożarami, klęskami żywiołowymi i innymi miejscowymi zagrożeniami. Do podstawowych zadań omawianej tu formacji należą m.in.:
- rozpoznawanie zagrożeń pożarowych i innych miejscowych zagrożeń;

- organizowanie i prowadzenie akcji ratowniczych w czasie pożarów, klęsk żywiołowych lub likwidacji miejscowych zagrożeń;

-wykonywanie pomocniczych specjalistycznych czynności ratowniczych w czasie klęsk żywiołowych lub likwidacji miejscowych zagrożeń przez inne służby ratownicze;

- kształcenie kadr dla potrzeb Państwowej Straży Pożarnej i innych jednostek ochrony przeciwpożarowej oraz powszechnego systemu ochrony ludności;

- nadzór nad przestrzeganiem przepisów przeciwpożarowych [54].

Innymi istotnymi podmiotami bezpieczeństwa powszechnego są m. in. instytucje wchodzące w skład Państwowego Ratownictwa Medycznego oraz Państwowa Inspekcja Sanitarna.

Celem funkcjonowania Państwowego Ratownictwa Medycznego jest realizacja zadań państwa dotyczących zapewnienia pomocy każdej osobie znajdującej się wstanie nagłego zagrożenia zdrowotnego [55]. Natomiast Państwowa Inspekcja Sanitarna została powołana do realizacji zadań z zakresu zdrowia publicznego, w celu ochrony zdrowia ludzkiego przed niekorzystnym wpływem szkodliwości i uciążliwości środowiskowych, zapobiegania powstawaniu chorób, w tym chorób zakaźnych. Instytucja ta sprawuje nadzór sanitarny oraz prowadzi działalność zapobiegawczą i przeciwepidemiczną W zakresie m.in. chorób zakaźnych [56].

Policja współdziała $\mathrm{z}$ podmiotami systemu bezpieczeństwa powszechnego w stanach nadzwyczajnych, w sytuacjach kryzysowych (zabezpieczenie dróg ewakuacyjnych oraz dostarczania pomocy humanitarnej, ochrona pozostawionego mienia na obszarach zagrożonych, ochrona osób ewakuowanych), oraz zabezpieczając miejsca niebezpieczne przed dostępem osób niepowołanych.

W czasie trwającego w 2020 r. w Polsce stanu zagrożenia epidemicznego (będącego sytuacją prawną wprowadzoną na danym obszarze w związku $\mathrm{Z}$ ryzykiem wystąpienia epidemii $\mathrm{w}$ celu podjęcia określonych w ustawie działań zapobiegawczych) i stanu epidemii (będącego sytuacją prawną wprowadzoną na danym obszarze w związku z wystąpieniem epidemii w celu podjęcia określonych w ustawie działań przeciwepidemicznych i zapobiegawczych dla zminimalizowania skutków epidemii) Policja kooperując z innymi podmiotami systemu zapewniała przestrzeganie przepisów prawa mających na celu ograniczenia skali masowych zachorowań zakaźnych [57].

Przyczyniając się do utrzymywania bezpieczeństwa powszechnego Policja poprzez swoich 
przedstawicieli wchodzi w skład interdyscyplinarnych zespołów zarządzania kryzysowego (zarówno na poziomie krajowym, wojewódzkim, powiatowym, jak i gminnym) [58]. Policja działa również $w$ rejonie zagrożenia bezpieczeństwa powszechnego, a jej aktywność może przyjąć formy:

- operacji policyjnej - rozumianej jako „zespół przedsięwzięć organizacyjnych, taktycznych i materiałowo-technicznych polegających na wykonywaniu zadań służbowych przez siły przynależne do różnych rodzajów służb Policji, w celu przeciwdziałania lub likwidacji zdarzeniom szczególnym, gdy z posiadanych informacji wynika wysokie i przewidywalne ryzyko ich wystąpienia";

-akcji policyjnej - rozumianej jako „zespół przedsięwzięć organizacyjnych, taktycznych i materiałowo-technicznych polegających na wykonywaniu zadań służbowych przez siły podległe komendantowi wojewódzkiemu Policji lub komendantowi powiatowemu Policji właściwemu terytorialnie do miejsca wystąpienia zdarzeń szczególnych, do prowadzenia których może być wymagane użycie przydzielonych sił wsparcia, w celu przeciwdziałania lub likwidacji tym zdarzeniom, gdy $\mathrm{z}$ posiadanych informacji wynika wysokie i przewidywalne ryzyko ich wystąpienia, a podjęcie skutecznych działań nie wymaga zastosowania działań kontr terrorystycznych";

-zabezpieczenia prewencyjnego - rozumianego jako zespół przedsięwzięć organizacyjnych polegających na wykonywaniu zadań służbowych przez siły będące aktualnie w dyspozycji komendy powiatowej Policji właściwej terytorialnie dla miejsca zdarzeń szczególnych w celu przeciwdziałania tym zdarzeniom lub ich likwidacji, gdy z posiadanych informacji wynika zwiększone ryzyko ich wystąpienia, a podjęcie skutecznych działań nie wymaga zastosowania działań taktycznych pododdziałów Policji w sytuacji zagrożenia bezpieczeństwa lub naruszenia porządku publicznego";

-zabezpieczenia doraźnego - rozumianego jako „wykonywanie zadań służbowych przez siły będące aktualnie w dyspozycji komendy powiatowej Policji właściwej terytorialnie dla miejsca zdarzeń szczególnych w celu przeciwdziałania tym zdarzeniom lub ich likwidacji, gdy $\mathrm{z}$ posiadanych informacji wynika bardzo niskie ryzyko ich wystąpienia, a podjęcie skutecznych działań nie wymaga zastosowania działań taktycznych pododdziałów Policji w sytuacji zagrożenia bezpieczeństwa lub naruszenia porządku publicznego" [59].

Współdziałając $\mathrm{z}$ podmiotami systemu bezpieczeństwa powszechnego Policja wykonuje zadania wspomagające, ochraniające, zapewniające ład publiczny. Jednak jej znaczenie jest nie do przecenienia. Policja posiada szeroki wachlarz oddziaływań na społeczeństwo tak by praca grup ratowniczych była niezakłócana. Posiada również środki przymusu bezpośredniego, które może użyć dla ochrony ludzi lub grup ratowniczych.

\section{Zakończenie}

Policja wykonuje wiele zadań przypisanych prawem. Wynika to $z$ tego, że jest odpowiedzialna zarówno za zapewnienie bezpieczeństwa ludzi (ich życia, zdrowia i zasobów), jak również utrzymywania bezpieczeństwa i porządku publicznego.

W sferze bezpieczeństwa publicznego Policja odgrywa rolę pierwszoplanową. Jest głównym realizatorem zadań zmierzających do ograniczania przestępczości, jest organizatorem działań wspólnych $\mathrm{z}$ podmiotami pozapolicyjnym wpisującymi się $\mathrm{w}$ podsystem bezpieczeństwa publicznego. Inicjuje działania $u$ innych podmiotów, aktywizuje w kierunku podejmowania wspólnych przedsięwzięć na rzecz bezpieczeństwa lokalnego. Dzięki zaangażowaniu i sprawnemu działaniu Policji poziom przestępczości w Polsce obniża się, ludzie czują się coraz bezpieczniejsi, a praca tej formacji jest bardzo wysoko oceniana przez spoleczenstwo.

Aktywność Policji ma również znaczenie dla utrzymywania bezpieczeństwa powszechnego. Co prawda jej rola nie jest pierwszoplanowa lecz jej działania stanowią istotne wsparcie dla grup ratowniczych.

Mając na podsystemy bezpieczeństwa publicznego i powszechnego, w których funkcjonuje Policja wpisują się $\mathrm{W}$ system bezpieczeństwa wewnętrznego należy uznać, że omawiana tu formacja ma duże znaczenie dla funkcjonowania tego systemu. Owo znaczenie wynika ze zdolności tej formacji do prowadzenia działań wiodących $\mathrm{w}$ sferze utrzymywania bezpieczeństwa publicznego oraz działań wspomagających $\mathrm{w}$ sferze utrzymywania bezpieczeństwa powszechnego.

Mając powyższe na względzie należy uznać, że problem badawczy został rozwiązany, a założona na wstępie hipoteza badawcza została uznana za prawdziwą. Podsumowując należy również stwierdzić, że niniejsze przedsięwzięcie badawcze pozwoliło na osiągnięcie założonego celu.

\section{Bibliografia:}

1. Arystoteles, Polityka, PWN, thum. M. Szymański, Warszawa 2012, s. 25. 
2. Arystoteles, Etyka Nikomahejska, ttum. D. Gromska, PWN 2012, s. 87-88.

3. W. Tatarkiewicz, $O$ szczęściu, PWN, Warszawa 2010, s. 245-249.

4. M. Cieślarczyk, B. Wiśniewski, Wspótczesne rozumienie bezpieczeństwa, [w:] Bezpieczeństwo w teorii $i$ badaniach naukowych, red. B. Wiśniewski, WSPol Szczytno, s., Szczytno 2011, s.13.

5. B. Kogut, Edukacja dla bezpieczeństwa w instytucjach zhierarchizowanych na przykładzie Państwowej Straży Pożarnej, „Zeszyty Naukowe SGSP”, Nr74/2/2020, s. 231.

6. P. Lubiewski, Bezpieczeństwo państwa reminiscencje, "Zeszyty Naukowe Państwowej Wyższej Szkoły Zawodowej im. Witelona w Legnicy", nr 34(1)/2020, s. 53.

7. R. Gwardyński, Możliwości doskonalenia prewencyjnego Policji, AWL, Wrocław 2019, s. 61-63.

8. T. Kotarbiński, Traktat o dobrej robocie, Wyd. pierwsze, PWN, Warszawa 2020, s. 113.

9. S. Koziej, Między piektem a rajem. Szare bezpieczeństwo na progu XXI wieku, Wyd. Adam Marszałek, Toruń 2006, s. 7.

10. W. Kitler, Bezpieczeństwo narodowe RP. Podstawowe kategorie, uwarunkowania, system. AON, Warszawa 2011, s. 31.

11. B. Wiśniewski, Przygotowania obronne resortu spraw wewnętrznych, WSPol Szczytno, s., Szczytno 2014, s. 32.

12. R. Gwardyński, Bezpieczeństwo jako dzieło sprawcy impulsu dowolnego, [w:] Bezpieczeństwo personalne a bezpieczeństwo strukturalne, Tom IX, Zagrożenia miękkim i twardym przymusem, red. $\mathrm{T}$. Grabińska, P. Szczepański, AWL, Wrocław 2020, s. 87.

13. T. Pszczołowski, Mała encyklopedia prakseologii $i$ teorii organizacji, Ossolineum, Wrocław-Warszawa-Kraków-Gdańsk 1978, s. 25.

14. B. Wiśniewski, Praktyczne aspekty badań bezpieczeństwa, Difin, Warszawa 2020, s. 20.

15. B. Szlachta, Encyklopedia polityczna, [w:] Encyklopedia polityczna, Tom 1. red. J. Bartyzel, B. Szlachta, A. Wielomski, POLWEN, Warszawa 2007, s. 55.

16. A. Antoszewski, T. Łoś-Nowak, Państwo, [w:] Leksykon politologii, Wydanie II poprawione i uzupełnione, red. A. Antoszewski, R. Herbut, Atla2, Wrocław 1996, s. 261.

17. S. Ehrlich, Wstęp do nauki o państwie $i$ prawie, PWN, Warszawa 1979, s. 67-68.

18. W. Kitler, Bezpieczeństwo ... op. cit., s. 75. s.134.

19. B. Wiśniewski, Przygotowania..., op. cit.,

20. A. Antoszewski, T. Łoś-Nowak, Państwo..., op. cit., s. 262.

21. B. Wiśniewski, System bezpieczeństwa państwa. Konteksty teoretyczne i praktyczne, WSPol, Szczytno 2013, s. 29.
22. W. Kieżun, Sprawne zarzadzanie organizacja, Zarys teorii i praktyki, SGH, Warszawa 1997, s. 13.

23. Medyczny stownik encyklopedyczny, Wyd. pierwsze, red. M. Barczyński, J. Bogusz, Oficyna Wydawnicza, Kraków 1993, s. 143.

24. M. Foucault, Wyktad z 15 marca $1978 r$. [w:] Bezpieczeństwo, terytorium, populacja, thum. M. Herer, PWN, Warszawa 2014, s. 261.

25. B. Wiśniewski, Potrzeby i możliwości ksztatcenia kierowniczych kadr administracji publicznej $w$ zakresie bezpieczeństwa publicznego, [w:] Nauki spoteczne na rzec bezpieczeństwa wewnętrznego, red. P. Bogdalski, M. Nepelski, WSPol Szczytno 2014, s. 26.

26. Konstytucja Rzeczypospolitej Polskiej z dnia 2 kwietnia 1997 r. uchwalona przez Zgromadzenie Narodowe w dniu 2 kwietnia 1997 r., przyjęta przez Naród w referendum konstytucyjnym w dniu 25 maja 1997 r., podpisana przez Prezydenta Rzeczypospolitej Polskiej w dniu 16 lipca 1997 r. (Dz.U. $1997 \mathrm{nr} 78$ poz. 483z późn. zm.).

27. Ustawa z dnia 4 września 1997 r. o działach administracji rządowej (Dz.U. 2020 poz. 1220).

28. B. Wiśniewski, Wprowadzenie, [w:] Wspótczesny wymiar funkcjonowania Policji, red. B. Wiśniewski, Z. Piątek, Akademia Obrony Narodowej, Warszawa 2009, s. 7.

29. A. Misiuk, Instytucje bezpieczeństwa wewnętrznego w Polsce. Zarys dziejów (od X wieku do wspótczesności), WSPol, Szczytno 2012, s.359.

30. B. Wiśniewski, System..., op. cit., 122.

31. R. Gwardyński, Wybrane problemy działań prewencyjnych Policji, „Zeszyty Naukowe SGSP” Nr 74/2/2020, s. 303.

32. W. Kitler, Bezpieczeństwo... op. cit.,, s. 56.

33. Z. Ścibiorek, B. Wiśniewski, R.B. Kuc, A. Dawidczyk, Bezpieczeństwo wewnętrzne. Podręcznik akademicki, Wyd. Adam Marszałek, Torun 2015, s. 36.

34. T. Serafin, S. Parszowski, Bezpieczeństwo społeczności lokalnych. Programy prewencyjne $w$ systemie bezpieczeństwa, Difin, Warszawa 2011, s. 33.

35. A. Babiński, W poszukiwaniu definicji bezpieczeństwa publicznego, "Zeszyty Naukowe Państwowej Wyższej Szkoły Zawodowej im. Witelona w Legnicy", nr 35(2)/2020, s. 105.

36. Ustawa z dnia 6 kwietnia 1990 r. o Policji (Dz.U. 2020 poz. 360).

37. Ustawa $\mathrm{z}$ dnia 26 kwietnia 2007 r. o zarządzaniu kryzysowym (Dz.U. 2020 poz. 1856).

38. Ustawa z dnia 23 stycznia 2009 r. o wojewodzie i administracji rządowej w województwie (Dz. U. 2009 Nr 31 poz. 206 późn. zm.).

39. Ustawa z dnia 28 stycznia 2016 r. Prawo o prokuraturze (Dz. U. 2016 poz. 177 z późn. zm.).

40. Ustawa z dnia 12 października 1990 r. o Straży Granicznej (Dz.U. 1990 nr 78 poz. 462 z późn. zm.). 
41. Ustawa z dnia 24 sierpnia 2001 r. o Żandarmerii Wojskowej i wojskowych organach porządkowych (Dz. U. 2001 nr 123 poz. 1353 z późn. zm.).

42. Ustawa z dnia 8 grudnia 2017 r. o Służbie Ochrony Państwa (Dz.U. 2021 poz. 575).

43. Ustawa $z$ dnia 24 maja 2002 r. o Agencji Bezpieczeństwa Wewnętrznego oraz Agencji Wywiadu (Dz.U. 2020 poz. 27).

44. Ustawa z dnia 5 czerwca 1998 r. o samorządzie województwa (Dz. U. 1998 Nr 91 poz. 576 z późn. zm.).

45. Ustawa z dnia 5 czerwca 1998 r. o samorządzie powiatowym (Dz. U. $1998 \mathrm{Nr} 91$ poz. 578 z późn. zm.).

46. Ustawa z dnia 8 marca 1990 r. o samorządzie gminnym (Dz. U. 1990 Nr 16 poz. 95 z późn. zm.).

47. Ustawa z dnia 29 sierpnia 1997 r. o strażach gminnych (Dz.U. 2019 poz. 1795).

48. https://www.gov.pl/web/mswia/programograniczania-przestepczosci-i-aspolecznychzachowan-razem-bezpieczniej-im-wladyslawa-stasiaka (dostęp 30.05.2021 r.).

49. Strategia Bezpieczeństwa Narodowego, BBN, Warszawa 2014, s. 36.

50. W. Kitler, Bezpieczeństwo... op. cit., s. 55.

51. Z. Ścibiorek, B. Wiśniewski, R.B. Kuc, A. Dawidczyk, Bezpieczeństwo..., op. cit., s. 39.

52. Ustawa z dnia 18 kwietnia 2002 r. o stanie klęski żywiołowej (Dz.U. 2017 poz. 1897).

53. Biała Księga Bezpieczeństwa Narodowego Rzeczypospolitej Polskiej, BBN, Warszawa 2013, s. 66.
54. Ustawa z dnia 24 sierpnia 1991 r. o Państwowej Straży Pożarnej (Dz.U. 2020 poz. 1123).

55. Ustawa z dnia 8 września 2006 r. o Państwowym Ratownictwie Medycznym (Dz.U. 2020 poz. 882).

56. Ustawa z dnia 14 marca 1985 r. o Państwowej Inspekcji Sanitarnej (Dz.U. 2021 poz. 195).

57. Ustawa z dnia 5 grudnia 2008 r. o zapobieganiu oraz zwalczaniu zakażeń i chorób zakaźnych u ludzi (Dz.U. 2020 poz. 1845).

58. Ustawa $\mathrm{z}$ dnia 26 kwietnia 2007 r. o zarządzaniu kryzysowym (Dz.U. 2020 poz. 1856).

59. Zarządzenie nr 20 Komendanta Głównego Policji dnia 13 lipca 2020 r. w sprawie metod i form przygotowania i realizacji działań policyjnych $\mathrm{w}$ związku ze zdarzeniami szczególnymi, (Dz.Urz. KGP. z 2020 r. poz. 25.).

\section{* Оглядова стаття}

Стаття надійшла до редакції 01.12.2021. 